\title{
Manuscript Collections: The Papers of Amelia Jenks Bloomer and Dexter Bloomer
}

\author{
Cheryl Schmidt
}

THE NAMING of Bloomer School and of Bloomer Street in Council Bluffs, Iowa appears to stand as the city's finest irony. Amelia Bloomer, one of the most progressive reformers in temperance and women's rights in the nineteenth century, moved to Council Bluffs in 1855 during the years of her greatest influence. By that time the name Bloomer was a national household word -or nearly. Amelia Bloomer had gained recognition through her vocal support of temperance and women's rights, as publisher and editor of a magazine promoting those causes called The Lily, as a prominent lecturer, and as popularizer of the ladies' garment which bears her name. What a marked irony it is that the two visual tributes to the name of Bloomer in Council Bluffs do not honor the women's rights leader at all but honor her husband Dexter Bloomer, a school board member and local lawyer.

Dexter would have been the first to renounce the conferred distinction in favor of his wife. His book, The Life and Writings of Amelia Bloomer, clearly reveals his pride in her writings and her pioneering efforts in women's rights. His labor to preserve her manuscripts and publications and to record her biography proves his firm belief in the importance of her work. Indeed, to 
turn a phrase, behind this good woman stood a good man. Dexter's encouragement and support of his wife's ideals affirm this.

Amelia Bloomer is often overlooked as one of the major early women's rights leaders. Possible explanations for this are her distance from the heart of the movement in Seneca Falls, New York-she and Dexter moved away in 1853-at the apparent height of her influence, and the fact that Amelia was not as outspoken in the early years of the women's movement on the issue of suffrage as were her friends Elizabeth Cady Stanton or Susan $B$. Anthony (she introduced them in 1850). Her writings - apart from the unsigned Lily articles-were not published during her lifetime. Probably the biggest reason that Amelia Bloomer has not received serious attention from scholars during the twentieth century is that her name is irrevocably linked to the emblematic caricature of the women's movement-bloomers.

\begin{abstract}
A MELIA Jenks was born on May 27, 1818, in Homer, Cortlandt County, New York. She was the youngest child of Ananias Jenks, a clothier, and Lucy Webb Jenks, a Christian woman of New England Puritan background. Amelia attended the district school, where it was thought that a girl should be taught to do some reading, writing, grammar, and a little arithmetic. At the age of seventeen she became a district school teacher herself. After teaching a term, she moved to Waterloo, New York, to live with her sister. There she was governess to the children of Mr. and Mrs. Owen Chamberlain for over two years.
\end{abstract}

In Waterloo she met Dexter Bloomer, a young law student from Seneca Falls. Dexter was of Quaker parentage, had taught school himself, and was one of the proprietors and editors of The Seneca County Courier. He and Amelia Jenks became engaged and, on April 15, 1840, they were married. Two events at their wedding and its subsequent celebration foreshadowed Amelia's later work. First, the clergyman omitted the word "obey" from the wedding rites. Later, Amelia pleasantly but firmly refused her new husband's earnest request to share a glass of wine with him at a party his friends held. Later in her 


\section{The Bloomer Papers}

life, women's equality and temperance became the major causes she espoused.

After the national election in 1840 Dexter began encouraging Amelia to write for his paper, saying that she wrote with grace and ease. Her subsequent anonymous articles for The Courier aroused great curiosity as to their author.

The Bloomers began attending local temperance gatherings in 1840, and Amelia's interest in temperance reform work initiated her expression of strong opinions in a newspaper called The Water Bucket, a temperance paper in Seneca Falls. The poor quality of much of the liquor at that time caused a deleterious effect in those people caught up in alcoholism. Temperance reformers, by and large, were fighting to halt the personal tragedies and public problems that resulted from drinking liquor.

On July 19,1848 , the Bloomers attended the famous convention in Seneca Falls on the topic of women's rights. They heard the resolutions and Mrs. Stanton's "Women's Declaration of Independence." But Amelia was not yet decided. Her established cause was temperance, and she did not agree with all the articles in the Declaration. She did not sign the resolutions or Declaration at those meetings.

In 1848 Amelia became an officer of the newly-formed Seneca Falls Ladies' Temperance Society. In that year, the Society determined to have a newspaper of its own. On January 1, 1849, The Lily was born. Although it was originally to have been written and edited by several members, nearly the entire burden fell on Amelia's shoulders. Of the first issue, two or three hundred copies were published, but through the years the subscription list grew until in 1853 it exceeded six thousand.

In the summer of 1849, Elizabeth Cady Stanton came to the post office in which Mrs. Bloomer served as deputy post-master. She proposed writing a column in The Lily under the name of Sunflower. Her articles for the publication began as literary and temperance-oriented, but gradually The Lily became a mouthpiece for Mrs. Stanton's women's rights ideas. Frances Gage, Mary C. Vaughan, and others became contributors to the monthly publication, and Amelia was converted to their way of 
thinking. She began writing women's reform articles herself.

In 1851, the Bloomer name was attached to the dress reform movement by accident. Elizabeth Smith Miller (a cousin of Mrs. Stanton's) appeared in Seneca Falls wearing the short skirt and Turkish trousers which she had designed and had made. Mrs. Stanton observed the ease with which her cousin climbed stairs holding a baby as well as a candle. Mrs. Stanton knew that she herself would have a struggle carrying nothing due to the confinement of her corset and the bulk of her petticoats, and she determined that a reform was in order. Mrs. Stanton and Amelia Bloomer both began wearing the costume. Amelia publicized it in The Lily and included pictures of herself in the outfit. The name bloomers caught on and stuck. Later, with advancing years and the introduction of the hoop skirts, Amelia put off the bloomer costume, but her name remains with bloomers to this day.

During the years of The Lily in Seneca Falls, Bloomer continued her support of the Temperance Society. She began to give lectures on both temperance and women's rights and served as a delegate to district temperance conventions. Through her work in the reform movements, as well as publicity from The Lily, Amelia Bloomer became known in the United States and abroad. In 1853, The Lily became a bi-monthly paper.

Suddenly, Dexter bought interest in a paper in Mt. Vernon, Ohio, and the Bloomers moved there from Seneca Falls in December, 1853. The 1854 issues of The Lily were printed and distributed from Mt. Vernon. Amelia also served as assistant editor for The Western Home Visitor, her husband's paper in Mt. Vernon, and contributed to it weekly. She remained actively involved in her major causes of women's reform and temperance.

In the spring of 1855 , the Bloomers moved from Mt. Vernon to Council Bluffs, Iowa. Amelia sold The Lily to Mary A. Birdsall of Richmond, Indiana, and she remained as corresponding editor. The Lily was published through December of 1856.

Council BLUFFs was where the Bloomers spent the rest of 


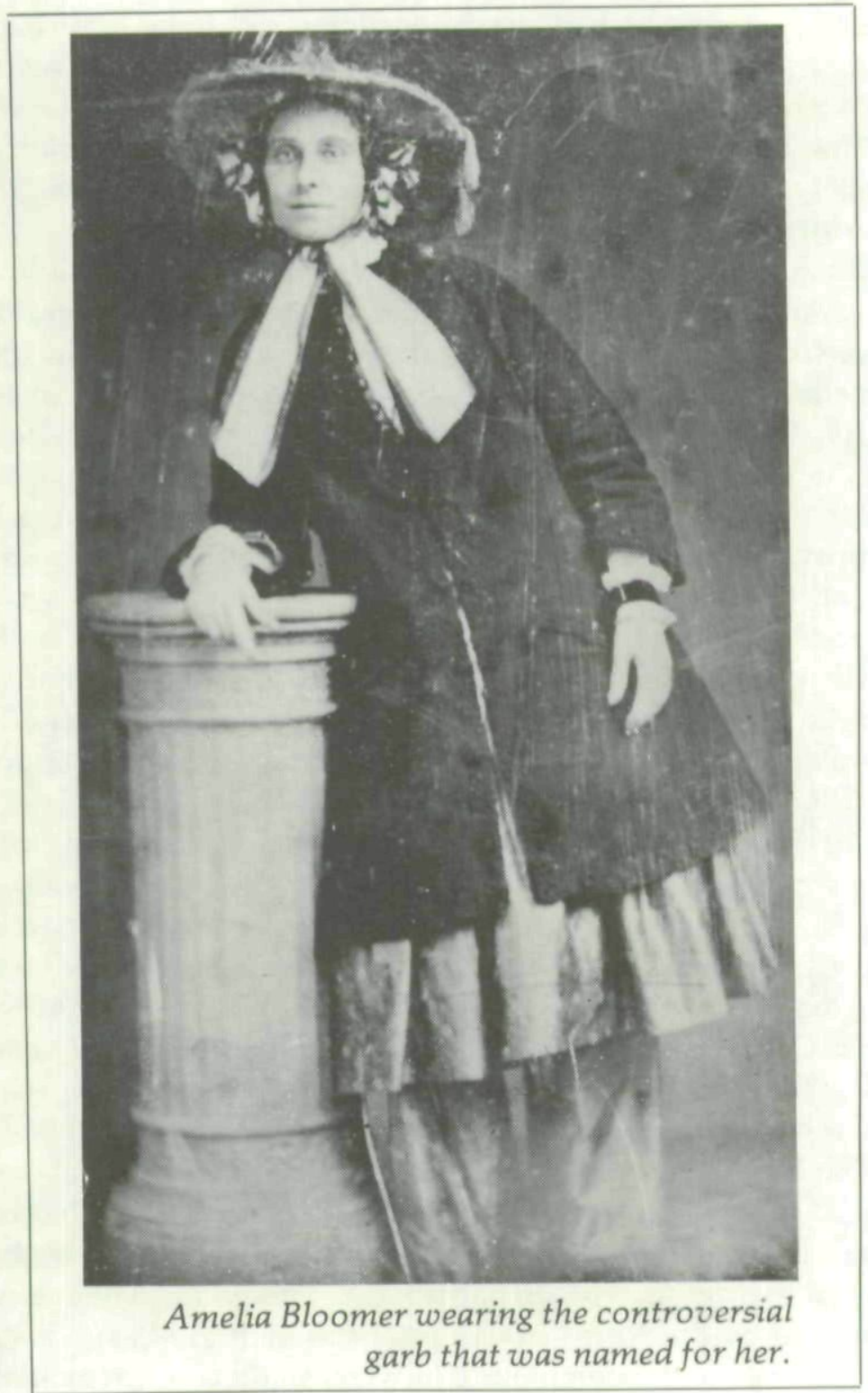

their continuously productive lives. Although they never had children of their own, they adopted two Civil War orphans who remained with them in Council Bluffs until they were of an age to establish themselves. Amelia remained an active supporter of 
the two causes she had championed and did some lecturing as health permitted. Many of her manuscripts which are accessible were written during the 1850s through the 1870s in Council Bluffs. In 1870, largely due to her efforts, the Woman Suffrage Society of Iowa was formed, and she was elected its first vicepresident.

On April 15, 1890, the Bloomers celebrated their 50th Wedding Anniversary in Council Bluffs. They received congratulations from friends and acquaintances across the nation. In 1891, Amelia suffered what was probably a stroke but recovered fairly. Three years later, on December 30, 1894, she died; burial was in Fairview Cemetery, Council Bluffs.

After his wife's death, Dexter Bloomer continued to work for improvement in the growing town of Council Bluffs. He was a major influence in the development of the public school system and served on both the local and state school boards. Dexter's death came on February 24, 1900, and he was buried by Amelia. They share a common stone, a plain marker. The words under Amelia's name are plain, too, but full of import: "A PIONEER OF WOMAN'S EMANCIPATION."

The Bloomer manuscript holdings that I have found are in five separate places: the Public Library in Council Bluffs, Iowa; the Iowa State Historical Department, Division of Historical Museum \& Archives in Des Moines, Iowa; the State Museum in Albany, New York; the New York Historical Society in New York City; and the Seneca Falls Historical Society in Seneca Falls, New York.

The only extant complete copy of the six volumes of The Lily which Mrs. Bloomer edited and published is her personal copy, placed in the New York State Museum at her death by her husband. It contains (in Amelia's hand) notes pertaining to authorship of articles and other particulars. The bound volume was damaged by the New York Capitol fire in 1911. Later, microfilm copies of the complete Lily were made and are available on inter-library loan through the Wisconsin and Minnesota Historical Societies. A microfilm copy is also available at the University of Nebraska at Omaha Library, and probably has been recently acquired by other universities due to the increased interest in women's studies. Although the articles in The Lily are 
often not signed, the fever and pitch usually will indicate a Bloomer temperance article. The Lily-which began as a modest temperance publication-evolved as an important magazine of early women's rights; its gradual transition pointed the way to the blossoming of the eloquent movement that achieved woman suffrage in 1920. Among the Bloomer manuscripts available in New York City are letters from Amelia to Charles Thiel, W. E. Amber, and Mrs. R. A. S. Janney, a prominent Ohio women's rights leader.

The Seneca Falls Historical Society in New York has the largest and most valuable collection of original Amelia Bloomer manuscripts. These unpublished manuscripts are lectures and essays by Amelia dating from the 1850 s to the 1870 s. They concern temperance and several women's rights issues: i.e., the right to vote, property rights of women, equal education, employment, motherhood. These are all in Amelia's own hand and are in need of arranging and editing. These manuscripts are available through inter-library loan on microfilm from Cornell University. The manuscripts number fifteen to twenty essays and lectures and are several hundred hand-written pages in length. Also available at the Seneca Falls Historical Society are letters to Amelia Bloomer from such friends as Susan B. Anthony and Elizabeth Cady Stanton.

The Public Library in Council Bluffs, Iowa, has a fine historical collection. Amelia Bloomer's own scrapbook is available for perusal. It includes an essay or speech as well as a subscription and distribution list (presumably for The Lily), all in Amelia's hand. Miss Mildred K. Smock, the librarian, is trying to obtain for the library a duplicate microfilm of the Cornell copy of Mrs. Bloomer's manuscripts. Although there are no other Amelia Bloomer manuscripts in the Council Bluffs Library, there are other holdings of interest such as a copy of The Lily and many letters written to Amelia Bloomer.

The manuscript holdings of major importance at the Iowa State Historical Department, Division of Historical Museum \& Archives in Des Moines are Dexter Bloomer's journals which date from November, 1859, to February, 1900. Dexter Bloomer's will (located in Council Bluffs) stipulated that his journals were to be placed in the Council Bluffs Public Library at his 
death, but sixteen years after that event his executor, J. D. Edmundson, donated them to the Division of Historical Museum \& Archives in Des Moines, perhaps thinking they would receive more attention there. Dexter's journals contain many points of interest to a study of early Iowa history and law or to a study of Amelia Bloomer. Included in the Bloomer collection in Des Moines are letters written by both Amelia and Dexter Bloomer.
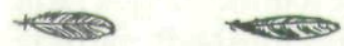

The following bibliography would be useful for a study of either Dexter or, more particularly, Amelia Bloomer. The best source of general information about Amelia is her biography, The Life and Writings of Amelia Bloomer, by Dexter Bloomer, now available in paperback. Charles Neilson Gattey's book, The Bloomer Girls, is a readily available and helpful book. (Several of the general books listed below are also listed in Gattey's bibliography.) Gattey advises that the Stanton and Anthony volumes of The History of Woman Suffrage would provide a sound general background for the women's movement. He also suggests that a random selection of newspapers and magazines of the 1850s would be helpful in analyzing Amelia Bloomer's career.

Published Works

Anthony, Katherine. Susan B. Anthony. Garden City: Doubleday, 1954.

Beitz, Ruth S. "Amelia Bloomer's Own Emancipation Proclamation." The Iowan 14 (1965):40-43, 54.

Bishop, Morris. The Exotics. New York: American Heritage Press, 1934.

Blackwell, Alice Stone. Lucy Stone. Boston: Little, Brown, 1920.

Bloomer, Dexter. The Life and Writings of Amelia Bloomer. Reprint Boston: Schocken Books, 1975. 


\section{The Bloomer Papers}

Bodichon, Barbara. Women and Work. New York: C. S. Francis and Co., 1859.

Branch, Douglas E. "The Lily and the Bloomer." Colophon Part 12 (1932).

Cromwell, Otelia. Lucretia Mott. Cambridge, Mass.: Harvard University, 1958.

Cunnington, C. Willet. A Dictionary of English Costume 9001900. Philadelphia: DuFours Editions, 1960.

Feminine Attitudes in the Nineteenth Century.

London: W. Heinemann, Ltd., 1935.

Handbook of English Costume in the 19th Century. Philadelphia: DuFours Editions, 1959.

Dorland, Wm. A. Newman. The Sum of Feminine Achievement. Boston: Stratford Company, 1917.

Dorr, Rheta. Susan B. Anthony. New York: Frederick A. Stokes Company, 1928.

Douglas, Emily Taft. Remember the Ladies. New York: Putnam, 1966.

Dunbar, Newell. "A Biography of Amelia Bloomer" (Review of The Life and Writings of Amelia Bloomer). Arena 15 (March 1896):678-684.

Earle, Alice. Two Centuries of Costume in America. New York: Macmillan and Company, Ltd., 1903.

Fatout, Paul. "Amelia Bloomer and Bloomerism." New York Historical Society Quarterly 36 (1952):361-374.

"First of the Flappers." Literary Digest 73 (May 13, 1922):44-46. Flexner, Eleanor. Century of Struggle. Cambridge: Belknap Press, 1959.

Fowler, O. S. "Intemperance and Tight Lacing." Works on Phrenology, Physiology, and Kindred Subjects. Manchester, England: J. Heywood, 1877.

Fox, L. H. "Pioneer Women's Rights." New York Historical Society Quarterly 42 (January, 1958):71-4.

Furnas, Robert, ed. Transactions and Reports of the Nebraska State Historical Society, vol. 1. Lincoln, Nebraska: State Journal Co., State Printers, 1885, 58-60.

Furniss, Harry. Some Victorian Women; Good, Bad, and Indiferent. New York: Dodd, Mead, 1923. 
Garrison, Wendell Phillips. William Lloyd Garrison, 18051879: The Story of His Life Told By His Children. 4 Vols. New York: Century, 1885.

Gattey, Charles Neilson, The Bloomer Girls. New York: Coward McCann, Inc., 1968.

Gonciar, B. "Amelia Jenks Bloomer." Hobbies 53 (1948):118119.

Green, H. and M. The Pioneer Mothers of America. New York: G. P. Putnam's Sons, 1912.

Grimke, Sarah. Letters on the Equality of the Sexes and the Condition of Women. Boston: I. Knapp, 1938.

Gue, Benjamin F. History of Iowa. 4 Vols. New York: Century History Company, 1903.

Gurko, Miriam. The Ladies of Seneca Falls. New York: Macmillan, 1974.

Hallowell, Anna Davis, ed. James and Lucretia Mott; Life and Letters. Houghton, Mifflin and Company, 1884.

Hanaford, Phebe A. Daughters of America. Boston: B. B. Russell, 1883.

Harper, Ida. The Life and Work of Susan B. Anthony. Indianapolis: Bowen-Merrill Company, 1898.

Hays, Elinor. Morning Star, A Biography of Lucy Stone. New York: Harcourt, Brace and World, 1961.

Holbrook, Stewart Hall. Dreamers of the American Dream. New York: Doubleday, 1957.

Lost Men of American History. New York: Macmillan, 1946.

Jensen, Oliver. The Revolt of American Women. New York: Harcourt, Brace, 1952.

Jordan, Philip D. "The Bloomers in Iowa." Palimpsest 20 (1939):295-309.

Keatley, J. H. "Amelia Bloomer." Annals of Iowa, Ser. 1, vol. 12 (July, 1874):190-194.

Kraditor, Aileen. Up from the Pedestal. Chicago: Quadrangle Books, 1968.

Laver, James. Manners and Morals in the Age of Optimism. New York: Harper and Row, 1966.

Lewis, David W. "Amelia Jenks Bloomer." Notable American Women 1607-1950. Ed. Edward T. James. Cambridge, Mass.: Belknap Press, 1971. 
Logan, Mary S. The Part Taken by Women in American History. Wilmington, Delaware: Perry-Nalle Publishing Co., 1912.

Lutz, Alma. Created Equal. New York: John Day Company, 1940.

Susan B. Anthony. Boston: Beacon, 1959.

McCracken, Elizabeth. The Women of America. New York: Macmillan Company, 1904.

Monro, D. H. "Godwin, Oakeshott and Mrs. Bloomer." Journal of the History of Ideas 35 (October-December 1974):611624.

Morris, Richard. Studies in the History of American Law. 2nd. ed. Philadelphia: J. M. Mitchell Co., 1959.

"Mrs. Bloomer's Pantaloons a la Turk" (Review of M. Bishop's The Exotics). New Yorker 16 (June 29, 1940):42.

Noun, Louise R. Strong-Minded Women. Ames, Iowa: Iowa State University Press, 1969.

O'Connor, Lillian. Pioneer Women Orators. New York: Columbia University Press, 1954.

Porter, Lorle Anne. "Amelia Bloomer: An Early Iowa Feminist's Sojourn on the Way West." Annals of Iowa 41 (1973):12421257.

Riegel, Robert E. American Feminists. Lawrence, Kansas: University of Kansas, 1963.

"Women's Clothes and Women's Rights." American Quarterly 15 (1963):391-394.

Stanton, Elizabeth Cady, in collaboration with Susan B. Anthony and Matilda Gage. History of Woman Suffrage. Vols. 1 and 2. New York: Fowler, 1881.

Stanton, E. C. Eighty Years and More-Reminiscences. New York: European Publishing Company, 1898.

Stanton, Theodore, and Blatch, Harriet. Elizabeth Cady Stanton. New York: Harper and Brothers, 1922.

Stong, Phil. Hawkeyes. New York: Dodd, Mead, 1940.

Thorpe, Margaret Farrand. Female Persuasion. New Haven: Yale University Press, 1949.

Vail, Robert W. Glenroie. "The Lily." New York Historical Society Quarterly 36 (1952):375.

Whitton, Mary Ormsbee. These Were the Women: U.S.A. 
1776-1860. New York: Hastings House, 1954.

Woolson, Abba. Woman in American Society. Boston: Roberts Brothers, 1973.

\section{Unpublished Material}

Albany, N.Y. New York State Museum. The Lily (1849-1856), bound volumes, A.B.'s personal copy with her notes in the margins. Microfilm copies of The Lily available.

Council Bluffs, Ia. Public Library. Amelia Bloomer's personal scrapbook. Letters to A.B. (includes correspondence from Francis Gage and Lucy Stone). "Memorial Sermon on the Death of Mrs. A. Bloomer." (January 13, 1895), by Reverend E. F. Babcock.

Des Moines, Ia. Iowa State Historical Department, Division of Historical Museum and Archives. Dexter Bloomer's personal journals, 1859-1900. Letters by D.B. to Charles Aldrich. Letter by Amelia Bloomer to Reverend Dugdale. Letter by A.B. to Charles Aldrich. Letter to A.B. by Mary Livermore.

Ithaca, N.Y. Cornell University Library. Microfilm of Amelia Bloomer's manuscripts of speeches and articles, 1850-1870s. (Originals in Seneca Falls Historical Society.)

New York City. New York Historical Society. Descriptive article on Amelia Bloomer. Letter by A.B. to Charles Thiel. Letters (3) by A.B. to Mrs. R. A. S. Janney. Letters (2) by A.B. to Mrs. G. Browne. Letter by A.B. to W. E. Ambler. Seneca Falls, N.Y. Seneca Falls Historical Society, 356 D.F. Manuscripts of speeches and articles, 1850-1870s, (originals), by Amelia Bloomer. Genealogy of the Bloomer/Jenks families. Reminiscences by Amelia Bloomer. Miscellaneous material including phrenological charts, memorabilia, letters to A.B. by various friends (including S. B. Anthony, E. C. Stanton, and others). 
Copyright of Annals of Iowa is the property of State of Iowa, by \& through the State Historical Society of Iowa and its content may not be copied or emailed to multiple sites or posted to a listserv without the copyright holder's express written permission. However, users may print, download, or email articles for individual use. 